\title{
Unchanged gene expression of glycogen synthase in muscle from patients with NIDDM following sulphonylurea-induced improvement of glycaemic control
}

\author{
H. Vestergaard ${ }^{1}$, S. Lund ${ }^{2}$, C. Bjørbak ${ }^{1}$, O. Pedersen ${ }^{1}$ \\ ${ }^{1}$ Steno Diabetes Center and Hagedorn Research Laboratory, Copenhagen, Denmark \\ ${ }^{2}$ Division of Endocrinology and Metabolism, University Clinic of Internal Medicine C, Aarhus Amtssygehus, Aarhus, Denmark
}

Summary We have previously shown that the mRNA expression of muscle glycogen synthase is decreased in non-insulin-dependent diabetic (NIDDM) patients; the objective of the present protocol was to examine whether the gene expression of muscle glycogen synthase in NIDDM is affected by chronic sulphonylurea treatment. Ten obese patients with NIDDM were studied before and after 8 weeks of treatment with a weight-maintaining diet in combination with the sulphonylurea gliclazide. Gliclazide treatment was associated with significant reductions in $\mathrm{HbA}_{1 \mathrm{C}}(p=0.01)$ and fasting plasma glucose $(p=0.005)$ as well as enhanced beta-cell responses to an oral glucose load. During euglycaemic, hyperinsulinaemic clamp $\left(2 \mathrm{mU} \cdot \mathrm{kg}^{-1} \cdot \mathrm{min}^{-1}\right)$ in combination with indirect calorimetry, a $35 \%(p=0.005)$ increase in whole-body insulin-stimulated glucose disposal rate, predominantly due to an increased nonoxidative glucose metabolism ( $p=0.02$ ) was demonstrated in the gliclazide-treated patients when com- pared to pre-treatment values. In biopsies obtained from vastus lateralis muscle during insulin infusion, the half-maximal activation of glycogen synthase was achieved at a significantly lower concentration of the allosteric activator glucose 6-phosphate $(p=0.01)$. However, despite significant increases in both insulin-stimulated non-oxidative glucose metabolism and muscle glycogen synthase activation in gliclazide-treated patients no changes were found in levels of glycogen synthase mRNA or immunoreactive protein in muscle. In conclusion, improved blood glucose control in gliclazide-treated obese NIDDM patients has no impact on the gene expression of muscle glycogen synthase. [Diabetologia (1995) 38: 1230-1238]

Key words Non-insulin-dependent diabetes mellitus, skeletal muscle, glycogen synthase, gene expression, sulphonylurea treatment.
Under clamp conditions of euglycaemia and hyperinsulinaemia glucose clearance in most patients with non-insulin-dependent diabetes mellitus (NIDDM) is characteristically decreased by $30-$ $50 \%$ with glucose storage as glycogen in skeletal muscle being the quantitatively most affected path-

Received: 13 January 1995 and in revised form: 18 April 1995

Corresponding author: Dr. H. Vestergaard, Steno Diabetes Center, Niels Steensens Vej 2, DK-2820 Gentofte, Denmark Abbreviations: NIDDM, Non-insulin-dependent diabetes mellitus; GS, glycogen synthase; G6P, glucose-6-phosphate; OGTT, oral glucose tolerance test; AUC, area under the curve; $\mathrm{HGO}$, hepatic glucose output; PCR, polymerase chain reaction; bp, base pair. way [1]. Several abnormalities in the activation of glycogen synthase (GS), the key enzyme in glycogen synthesis, in muscle from patients with NIDDM have been reported. In some [2-4] but not in all [5-7] studies a reduced GS activity ("total" GS activity) in the presence of a saturating concentration of the allosteric activator glucose 6-phosphate (G6P) has been found. Other investigations have shown an impaired GS activity in the presence of physiological concentrations of G6P $[7,8]$ or reduced in vivo insulin-mediated activation of GS [9]. Moreover, we recently found an impaired mRNA expression of GS in muscle from NIDDM patients [4]. Treatment with sulphonylureas [10], diet [11], and insulin [12] partially reverses the im- 
paired insulin-stimulated glycogen synthesis of muscle in NIDDM patients.

Improved blood glucose control in sulphonylureatreated NIDDM patients is thought to result from both increased insulin secretion and increased insulin action [13]. Thus, prolonged sulphonylurea therapy causes an increase in fasting and mean day-time serum insulin levels [13] as well as an increased insulin-stimulated glucose disposal to peripheral tissues and in some studies an increased insulin-mediated suppression of hepatic glucose production [13]. In the present protocol we addressed whether the sulphonylurea-induced improvement of glycaemic control in NIDDM patients is associated with an increase of the impaired muscle GS mRNA expression. Thus, in obese NIDDM patients who were assessed by euglycaemic, hyperinsulinaemic clamp in combination with indirect calorimetry we have examined the effect of 8 weeks of treatment with the sulphonylurea gliclazide on GS gene expression in skeletal muscle.

\section{Subjects and methods}

Subjects and study design. Ten patients with NIDDM participated in the study. All were Caucasians and sedentary; clinical data are presented in Table 1. Part of the clinical and clamp data have been published previously [14]. Before entering the study six patients were treated with a weight-maintaining diet in combination with sulphonylurea or metformin therapy and 4 were on weight-maintaining diet therapy alone. All anti-hyperglycaemic medication was withdrawn 2 weeks prior to the first clamp study.

Before and after 8 weeks of drug intervention the volunteers were examined with a $4-\mathrm{h} 75-\mathrm{g}$ oral glucose tolerance test (OGTT) and a euglycaemic, hyperinsulinaemic clamp in combination with indirect calorimetry and muscle biopsy sampling. All patients were prescribed an individualized energy balanced diet by a dietitian; the diet contained $45 \%$ energy as carbohydrate, $40 \%$ fat and $15 \%$ protein. The dietary treatment was maintained throughout the study period and the patients were supervised by the dietitian to ensure dietary compliance. Moreover, the participants were instructed to continue their usual physical activity. Dosage of gliclazide was adjusted individually based on absence of glucosuria. After the first 2 weeks of individualized drug treatment, gliclazide was fixed at an oral dosage of 80-320 $\mathrm{mg} /$ day, given once or twice a day.

The NIDDM patients as defined by the National Diabetes Data Group criteria [15] were recruited from the outpatient clinic at the Steno Diabetes Center. Only NIDDM patients with a fasting serum C-peptide level greater than $0.3 \mathrm{nmol} / 1$ were included in the protocol. The patients had no clinical or biochemical signs of diabetic complications and no subject was taking any other medication known to influence glucose and lipid metabolism. Prior to participation the purpose and risks of the study were carefully explained to all of the volunteers and their informed consent was obtained. The protocol was approved by the local ethical committee of Copenhagen and was in accordance with the Helsinki Declaration.

Oral glucose tolerance test. On the first day of each study period the patients performed a 75-g OGTT after a 10-h over-
Table 1. Clinical characteristics of study participants

\begin{tabular}{lcl}
\hline & \multicolumn{2}{c}{ Study group } \\
\cline { 2 - 3 } & 1 st Clamp & 2nd Clamp \\
\hline Age (years) & $51(41-65)$ & - \\
Sex (female/male) & $4: 6$ & - \\
Duration of diabetes (years) & $5 \pm 1$ & - \\
Body mass index (kg/m ${ }^{2}$ ) & $32.3 \pm 0.7$ & $32.6 \pm 0.8$ \\
Body weight (kg) & $93.9 \pm 3.1$ & $94.9 \pm 3.5$ \\
Fat-free mass (kg) & $52.8 \pm 2.0$ & $53.1 \pm 2.2$ \\
HbA $A_{1 \mathrm{C}}$ (\%) & $8.0 \pm 0.5$ & $7.1 \pm 0.4^{\mathrm{a}}$ \\
Plasma glucose (mmol/l) & & \\
Basal & $11.5 \pm 1.3$ & $8.6 \pm 0.9^{\mathrm{b}}$ \\
Hyperinsulinaemia & $5.4 \pm 0.1$ & $5.4 \pm 0.1$ \\
Serum insulin (pmol/l) & & \\
Basal & $93 \pm 21$ & $109 \pm 20$ \\
Hyperinsulinaemia & $1143 \pm 75$ & $1191 \pm 54$ \\
Plasma NEFA (mmol/l) & & \\
Basal & $0.72 \pm 0.06$ & $0.63 \pm 0.06$ \\
Hyperinsulinaemia & $0.10 \pm 0.01$ & $0.08 \pm 0.01$ \\
Serum C-peptide (nmolll) & & \\
Basal & $0.63 \pm 0.10$ & $0.83 \pm 0.13^{\mathrm{b}}$ \\
Hyperinsulinaemia & $0.21 \pm 0.04$ & $0.41 \pm 0.06^{\mathrm{b}}$ \\
\hline Means SEM & &
\end{tabular}

Means \pm SEM

${ }^{\mathrm{a}} p=0.01$ vs 1 st clamp; ${ }^{\mathrm{b}} p=0.005$ vs 1 st clamp

night fast. No medication was given in the morning before the test.

Euglycaemic hyperinsulinaemic clamp. On the second day of each study period the patients underwent a euglycaemic hyperinsulinaemic $\left(2 \mathrm{mU}\right.$ insulin $\cdot \mathrm{kg}^{-1} \cdot \mathrm{min}^{-1}$ ) clamp after a 10 $\mathrm{h}$ overnight fast. Details of the clamp technique have been described previously $[16,17]$.

Steady-state periods were defined as the last 30 min during basal measurements $(-30-0 \mathrm{~min})$ and as the last $30 \mathrm{~min}$ during insulin-stimulated measurements (210-240 min).

Glucose disposal. Total glucose disposal rate was calculated from the plasma concentrations of tritiated glucose and plasma glucose using Steele's non-steady-state equations [18]. Total peripheral glucose uptake was corrected for urinary glucose loss.

Glucose and lipid oxidation. Indirect calorimetry was performed using a flow-through canopy gas analyser system (Deltatrac Metabolic Monitor, Datex, Helsinki, Finland) as described previously [17]. Rates of oxidation were calculated from Frayn's equation [19]. Non-oxidative glucose metabolism was calculated as the difference between total glucose disposal rate and glucose oxidation, as determined by indirect calorimetry.

Muscle biopsies. Percutaneous muscle biopsies (about $400 \mathrm{mg}$ ) were obtained under local anaesthesia (1\% lidocaine without epinephrine) from the vastus lateralis muscle approximately $20 \mathrm{~cm}$ above the knee, using a modified Bergström needle (Stille-Werner, Copenhagen, Denmark). Muscle samples were blotted to remove blood and were frozen within $30 \mathrm{~s}$ in liquid nitrogen, and stored at $-80^{\circ} \mathrm{C}$ until assayed.

$R N A$ extraction. Muscle biopsies were homogenized in a 4 $\mathrm{mol} / \mathrm{l}$ guanidinium thiocyanate solution and subsequently to- 
tal RNA was isolated on an Applied Biosystems 341 Nucleic Acid Purification System (Applied Biosystems, Inc., Foster City, Calif., USA). Quantity and purity of the total RNA were determined by absorbance at 260 and $280 \mathrm{~nm}$. Prior to analysis the integrity of RNA samples was controlled on a $1.0 \%$ denaturating agarose gel. Ribosomal bands were visualized by ethidium bromide staining and subsequent ultraviolet illumination. No signs of degradation were found in any of the samples.

Oligonucleotides used for polymerase chain reaction (PCR) amplification. Oligonucleotides were synthesized on an Applied Biosystems 394 DNA/RNA Synthesizer and applied to an NAB-10 column (Pharmacia P-L Biochemicals Inc., Milwaukee, Wis., USA) and used without further purification. Fluorescein labelling of primers was done during synthesis, using the Fluore Prime Amidite (Pharmacia). The human muscle GS primers were $(5 '$-primer) 5'-ACCTGGCTTATTCCCAACTGCTC-3' and (3'-primer) 5'-FAGTGACCTCAGTTCTGGATCATG-3'. The rabbit beta-globin primers were (5'primer) 5 '-TTTGGCAAAGAATTCACTCCTCAG-3' and (3'-primer) 5'-FGATGCTCAAGGGGCTTCATGATG-3' $(\mathrm{F}=$ fluorescein labelling).

cDNA synthesis and PCR amplification. cDNA was synthesized from 1.0- $\mu$ g total RNA in $25-\mu$ l reactions containing (in mmol/l) 50 Tris- $\mathrm{HCl}$ (pH 8.3), $75 \mathrm{KCl}, 3 \mathrm{MgCl}_{2}, 10$ DTT, 0.2 dNTP's, 40 units RNasin (Promega, Madison, Wis., USA), $0.625 \mu \mathrm{g}$ Oligo (dT) 18,400 units M-MLV RT (Life Technologies, Gaithersburg, Md. USA) and 2.5 pg rabbit $\beta$-globin mRNA (Clontech Laboratories, Inc., Palo Alto, Calif., USA). The reactions were performed at $37^{\circ} \mathrm{C}$ for $1 \mathrm{~h}$, followed by an enzyme inactivation during incubation at $95 \mathrm{C}$ for $10 \mathrm{~min}$. Each 50- $\mu$ l PCR reaction was carried out with $5 \mu \mathrm{l}$ of cDNA reaction mixture as template and the assay conditions were (in mmol/1) 10 Tris- $\mathrm{HCl}(\mathrm{pH} 9.0), 50 \mathrm{KCl}, 1.5 \mathrm{MgCl}_{2}, 0.1 \%$ Triton $\mathrm{X}-100,0.2 \mathrm{dNTP}$ 's, $0.2 \mu \mathrm{mol} / \mathrm{l}$ of each of the four oligonucleotide primers and 1.25 unit Taq DNA polymerase (Promega). The mixture was sealed with $25 \mu \mathrm{l}$ mineral oil and after initial denaturation at $95^{\circ} \mathrm{C}$ for $3 \mathrm{~min}$, the samples were subjected to 17 cycles of amplification: annealing at $55^{\circ} \mathrm{C}$ for $30 \mathrm{~s}$, extension at $72^{\circ} \mathrm{C}$ for $30 \mathrm{~s}$ and denaturation at $94^{\circ} \mathrm{C}$ for $30 \mathrm{~s}$, followed by a final extension at $72^{\circ}$ for $5 \mathrm{~min}$.

Analysis of human skeletal muscle GS mRNA. Five microlitres of each PCR reaction was mixed with $5 \mu$ of stop buffer (formamide with $5 \mathrm{mg} / \mathrm{ml}$ dextran blue), denaturated at $90^{\circ} \mathrm{C}$ for $3 \mathrm{~min}$ and loaded onto a $6 \%$ pre-mixed polyacrylamide gel (Life Technologies) on an Automated Laser Fluorescence DNA sequencer (Pharmacia). The ratio between the GS and rabbit globin fluorescein-labelled PCR products was determined by calculating the area under the curves (AUC) using Fragment Manager software (Pharmacia, Uppsala, Sweden).

The combined use of reverse transcription followed by PCR (RT-PCR) has been shown to be 1000-10000 times more sensitive than the traditional RNA blot techniques [20-22]. The exquisite sensitivity of the RT-PCR makes it possible to detect mRNA's of extremely rare abundance as well as mRNA in a small number of cells or in small amounts of tissue samples from in vivo sources. We add the rabbit $\beta$-globin mRNA in fixed amounts to each tube as an external standard to correct for variation in tube-to-tube cDNA synthesis efficiency and for variations in amplification efficiency. Thereby we circumvent the use of the traditional housekeeping genes such as $\beta_{2}$ microglobulin or actins as internal standard since mRNA levels of these genes do not always remain constant during alterations of metabolic states [23-25].

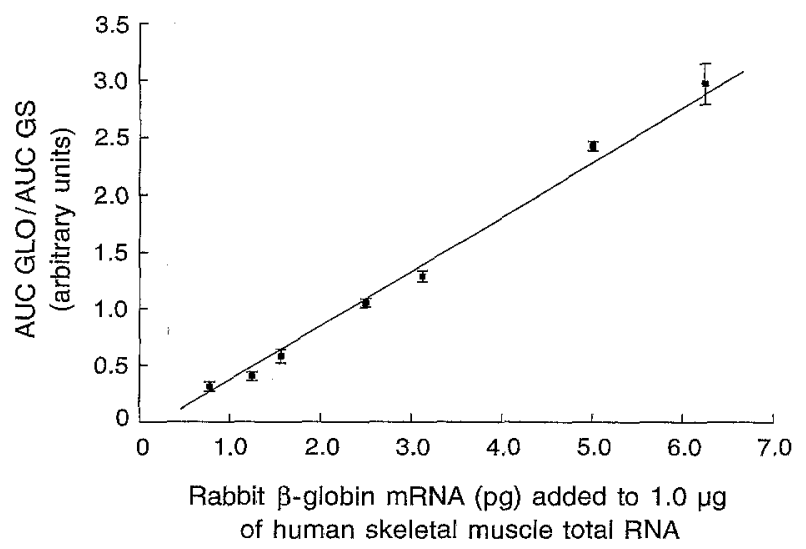

Fig. 1. Titration curve of PCR-based measurement of glycogen synthase (GS) mRNA in human skeletal muscle. One microgram of human muscle total RNA was mixed with increasing amounts of rabbit $\beta$-globin (GLO) mRNA, and subjected to RT-PCR amplification, with primers specific to human GS cDNA and to rabbit $\beta$-globin cDNA, respectively. One primer in each primer set was fluorescein labelled. Samples were withdrawn after 15, 17 and 20 cycles, respectively, and loaded onto a sequencing gel on an automatic DNA laser sequencer. After electrophoresis the AUC were determined. Results are mean \pm SD of the samples from the three different cycles plotted against the amount of mixed rabbit $\beta$-globin mRNA

Validation of competitor-based PCR analysis of GS $m R N A$. One microgram of total RNA isolated from muscle biopsies was mixed with a known amount of rabbit $\beta$-globin mRNA as external standard, reverse transcribed and PCR-amplified using two sets of primers, one for the GS cDNA and one for the rabbit $\beta$-globin cDNA. One primer in each set was fluorescein labelled. Separation and quantification of the PCR products were performed on an Automated Laser Fluorescence sequencer, using denaturating polyacrylamide gel-electrophoresis and the Fragment Manager software, respectively. The primers used generated a 145-base pair (bp) fragment of rabbit $\beta$-globin (RABGLO) cDNA and a 129 bp fragment of human GS cDNA. The two RABGLO primers are complementary to sequences in the coding region and the 3 ' untranslated region [26], respectively, while both GS primers are complementary to sequences in the $3^{\prime}$ untranslated region of the gene [27]. The RABGLO primers did not amplify the human $\beta$-globin gene and none of the primer sets generated any detectable products using human total RNA or rabbit $\beta$-globin mRNA as templates in PCR reactions after 17 cycles (data not shown).

In order to validate this method, serial dilutions of rabbit $\beta$ globin mRNA were added to the same amount of human total RNA, reverse transcribed and co-amplified together with GSspecific primers. Samples were withdrawn after 15, 17 and 20 cycles, respectively, and the AUC of RABGLO/AUC of GS ratios was calculated (Fig.1). It was found that both the competitor and the target genes were amplified with the same efficiencies up to 20 cycles and that the AUC of RABGLO/AUC of GS ratios varying from 0.3 to 3.0 are in the linear range. This corresponds to a range of 0.3 to 3.0 of GS/RABGLO in which all patient samples were found. All data were obtained during the exponential phase of the reactions before the products generated plateaus due to consumption of necessary components or generated inhibitors characteristic of PCR. The coefficient of variation of the method is 0.10 ( $n=18$ separate determinations performed in triplicate). 
Preparation of GS antipeptide antibody and GS immunoblotting were performed as described in detail earlier [17]. GS antibody was produced against nine amino acids $\left(\left(\mathrm{NH}_{2}\right)\right.$ TSSLGEERN) in the GS carboxy-terminus. Quantitative scanning of autoradiograms was performed within the linear response range, as determined by a standard curve of total GS protein using a Shimadzu CS 9000 flying spot densitometer (Shimadzu Corp., Tokyo, Japan). When six different samples from the same muscle biopsy were analysed for GS protein the interassay coefficient of variation was 0.11 .

Determination of GS activity in human muscle. Extraction of muscle proteins and assays for GS activity and analysis of protein content in muscle preparations were performed as described previously $[17,28]$. The interassay coefficients of variation were 0.12 for $A_{0.5}$ and 0.13 for total $G S$ activity $(n=10$ separate experiments performed on the same muscle).

To exclude any influence of day-to day variation, muscle samples from the same patient were prepared and analysed for GS mRNA and protein levels as well as for GS activities at the same time.

Other analytical procedures. Glucose in plasma and in urine was measured by a hexokinase method [29]. Serum insulin and $\mathrm{C}$-peptide concentrations were analysed by a two-site sandwich ELISA method and RIA, respectively $[30,31]$. $\mathrm{HbA}_{1 \mathrm{C}}$ was measured by an HPLC method (normal range 4.1-6.1\%). Tritiated glucose in plasma was analysed as described previously [32]. Non-esterified fatty acids (NEFA) in plasma were determined by the method of Itaya and Michio [33]. Fat free body mass (FFM) was measured using the impedance technique [34].

\section{Statistical analysis}

Statistical analysis was performed with the SPSS package (Statistical package for the social sciences). Non-parametric statistics were used: Wilcoxon test for paired data and Spearman's test for correlation analysis. $p$ values less than 0.05 were considered significant. All data in text and figures are given as mean \pm SEM.

\section{Results}

Metabolic control. After 8 weeks of gliclazide treatment fasting plasma glucose and $\mathrm{HbA}_{1 \mathrm{C}}$ levels improved significantly (Table 1 ).

As seen in Figure 2, there was a decrease in plasma glucose levels during the OGTT following gliclazide treatment. Calculating the mean incremental plasma glucose AUC a significant decrease was seen after 8 weeks of treatment $(1237 \pm 151$ vs $945 \pm$ $148 \mathrm{mmol} \cdot 1^{-1} \cdot \min ^{-1}, p=0.01$, pre- vs post-treatment, respectively). The calculated mean incremental serum insulin and serum C-peptide areas did not change significantly after 8 weeks of drug treatment (insulin: $23 \pm 5$ vs $30 \pm 8 \times 10^{3} \mathrm{pmol} \cdot \mathrm{1}^{-1} \cdot \mathrm{min}^{-1}$ (NS), pre- vs post-treatment, respectively; C-peptide: $106 \pm 16$ vs $139 \pm 36 \times 10^{3} \mathrm{pmol} \cdot \mathrm{I}^{-1} \cdot \mathrm{min}^{-1}(\mathrm{NS})$, prevs post-treatment, respectively).

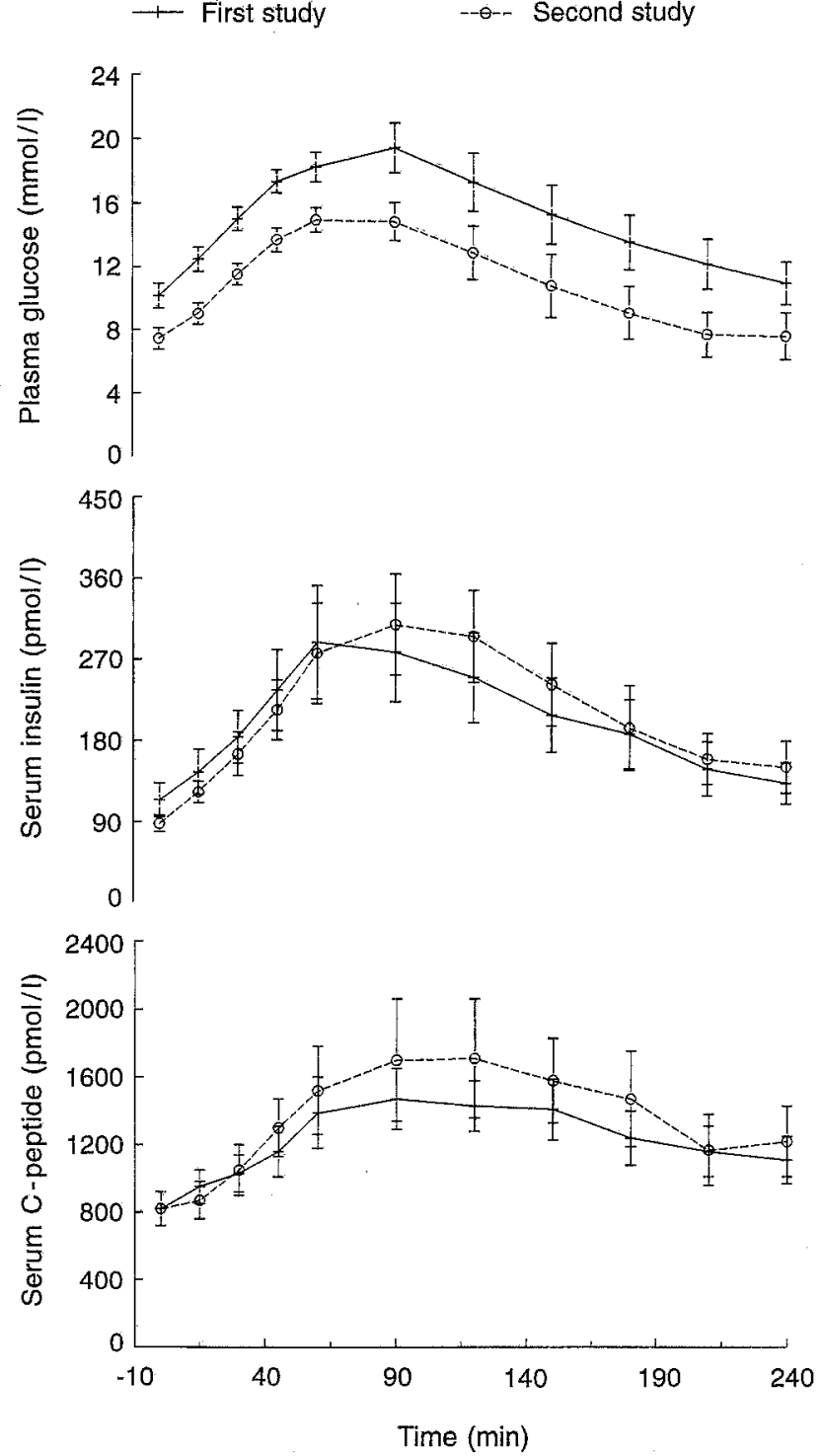

Fig.2. Plasma glucose, serum insulin and serum C-peptide concentrations in response to OGTT (means \pm SEM) in ten NIDDM patients before (solid lines) and after (dashed lines) 8 weeks of treatment with gliclazide. Mean incremental plasma glucose AUC was significantly smaller after 8 weeks of gliclazide treatment when compared to the pre-treatment period $(p=0.01)$

A significantly negative correlation was demonstrated between the change in mean incremental plasma glucose area after gliclazide treatment and the change in mean incremental serum insulin area $(r=-0.76, p=0.01)$.

Euglycaemic clamp and indirect calorimetry studies. Similar serum insulin levels were found in the basal state before and after the drug intervention (Table 1). Likewise, during insulin infusion similar steady-state serum insulin levels were obtained before and after therapy. Serum C-peptide levels in the basal state increased significantly after 8 weeks of therapy $(p=0.005)$ when compared to the pre-interven- 
tion finding. During hyperinsulinaemia similar results were obtained with a significantly higher level of serum C-peptide after 8 weeks of treatment $(p=0.005$ vs pre-treatment).

After gliclazide treatment for 8 weeks hepatic glucose output (HGO) decreased in seven out of ten patients while the remaining three patients showed an increase in HGO $(p>0.1)$ (Table 2). However, insulin-stimulated glucose disposal rate $(\mathrm{M})$ increased significantly in the gliclazide-treated group (8.8 \pm 0.9 vs $11.9 \pm 2.0 \mathrm{mg} \cdot \mathrm{kg} \mathrm{FFM}^{-1} \cdot \mathrm{min}^{-1}, p=0.005$, pre- vs post-treatment, respectively) predominantly due to a significantly increased non-oxidative glucose metabolism $\left(5.4 \pm 0.9\right.$ vs $8.2 \pm 1.9 \mathrm{mg} \cdot \mathrm{kg} \mathrm{FFM}{ }^{-1} \cdot \mathrm{min}^{-1}$, $p=0.02$, pre- vs post-treatment, respectively).

A significantly positive correlation was demonstrated between the increase in insulin-stimulated glucose disposal rate after intervention and the increase in mean incremental serum insulin level during OGTT $(r=0.68, p=0.04)$. No significant correlation was found between the decrease in mean incremental plasma glucose AUC after intervention and HGO in the basal state $(r=0.57, p=0.11)$.

Plasma levels of NEFA in the basal state were similar before and after therapy, and they were equally suppressed during intravenous insulin infusions (Table 1).

Glycogen synthase $m R N A$. The abundance of the specific GS mRNA relative to rabbit $\beta$-globin mRNA (external control) was assessed using the PCR technique. The relative amount of GS mRNA showed a four- to five fold variation within the group of patients. However, no significant difference in the levels of GS-specific mRNA was found after gliclazide treatment (Fig. 3A).

Glycogen synthase immunoreactive protein level. The amount of GS immunoreactivity in homogenates from human skeletal muscle was quantitated by immunoblotting using antipeptide antisera specific for GS. In all participants a dominant band of $84 \mathrm{kDa}$ was identified for GS immunoreactive protein in the basal state (Fig.3B, upper panel). Densitometric scanning of autoradiograms showed no difference in the relative level of GS protein in the basal state when results were adjusted for equal amounts of protein (98 \pm 4 vs $105 \pm 5$ optical density (OD) unit/ $100 \mu \mathrm{g}$ protein ( $\%$ of internal standard)(NS), pre- vs post-treatment, respectively (Fig. 3B, lower panel)).

Euglycaemia and hyperinsulinaemia for $4 \mathrm{~h}$ did not give rise to any significant change in the immunoreactive protein level of GS $(102 \pm 6$ vs $104 \pm 4$ OD unit $/ 100 \mu \mathrm{g}$ protein (\% of internal standard)(NS), pre- vs post-treatment, respectively (Figure 3B, lower panel)). Using the C-terminus antipeptide antibody against GS we were able to recognize that more minor bands with apparent molecular
Table 2. Total whole body glucose disposal rate, oxidative and non-oxidative glucose metabolism as well as lipid oxidation rates in the basal state and after $4 \mathrm{~h}$ of euglycaemic hyperinsulinaemic clamp in NIDDM patients characterized in Table 1

\begin{tabular}{lcc}
\hline & \multicolumn{2}{l}{ Study group } \\
\cline { 2 - 3 } & 1st Clamp & 2nd Clamp \\
\hline Basal period & $\left(\mathrm{mg} \cdot \mathrm{kg} \mathrm{FFM}^{-1} \cdot \mathrm{min}^{-1}\right)$ \\
Hepatic glucose output & $2.9 \pm 0.1$ & $2.8 \pm 0.1$ \\
Total glucose disposal rate & $3.3 \pm 0.1$ & $3.2 \pm 0.2$ \\
Oxidative metabolism & $1.3 \pm 0.3$ & $1.5 \pm 0.2$ \\
Non-oxidative metabolism & $2.0 \pm 0.3$ & $1.7 \pm 0.2$ \\
Hyperinsulinaemic period & & \\
Hepatic glucose output & $-1.9 \pm 0.4$ & $-4.0 \pm 1.4^{\mathrm{a}}$ \\
Total glucose disposal rate & $8.8 \pm 0.9$ & $11.9 \pm 2.0^{\mathrm{b}}$ \\
Oxidative metabolism & $3.5 \pm 0.3$ & $3.8 \pm 0.2$ \\
Non-oxidative metabolism & $5.4 \pm 0.9$ & $8.2 \pm 1.9^{\circ}$ \\
Lipid oxidation & & \\
Basal period & $1.9 \pm 0.1$ & $1.6 \pm 0.1$ \\
Hyperinsulinaemic period & $1.2 \pm 0.1$ & $0.8 \pm 0.1^{\mathrm{a}}$ \\
\hline
\end{tabular}

Means \pm SEM. ${ }^{a} p=0.05$ vs 1 st clamp; ${ }^{b} p=0.005$ vs 1 st clamp; ${ }^{c} p=0.02$ vs 1 st clamp

The second clamp was performed after an 8-week period with gliclazide treatment

weights of $82-80 \mathrm{kDa}$ were dissociated from the dominant band with $\mathrm{M}_{\mathrm{r}}$ of $84 \mathrm{kDa}$. The increased electrophoretic mobility of GS immunoreactivity may reflect the dephosphorylating effect of insulin on GS. In vivo insulin exposure before and after intervention had similar effects on GS immunoreactivity in muscle (Fig.3B, upper panel).

Glycogen synthase activity. Total muscle GS activity was similar in the basal state before and after the 8week period as well as after insulin infusion (Table 3). Fractional activity of GS in the basal state at the physiological concentration of G6P $(0.1 \mathrm{mmol} / \mathrm{l})$ was similar before and after the examination period and insulin infusion increased the fractional activity of GS equally. No correlation could be demonstrated between the change in $\mathrm{HbA}_{\mathrm{IC}}$ and the change in fractional activity of GS (G6P $0.1 \mathrm{mmol} / 1)$ in the gliclazide-treated patients $(r=-0.21 ; p=0.55)$.

The allosteric activation of GS by G6P showed that $A_{0.5}$ (the G6P concentration that half-maximally stimulates the enzyme) decreased significantly from the basal to the hyperinsulinaemic level, both before and after the 8-week period. The decrement in $\mathrm{A}_{0.5}$ was numerically higher after treatment $(0.24 \pm 0.03$ vs $0.14 \pm 0.01 \mathrm{mmol} / 1, p=0.01$ ), i. e. the relative activation of GS by G6P was $39 \%$ higher after gliclazide therapy (Table 3 ). No correlation could be demonstrated between the change in $\mathrm{HbA}_{\mathrm{IC}}$ and the change in $\mathrm{A}_{0.5}$ in the gliclazide-treated patients $(r=-0.21$; $p=0.56$ ).

The kinetics of skeletal muscle GS activation by G6P exhibit positive cooperativity as demonstrated by a Hill coefficient greater than 1 . The Hill coeffi- 
A

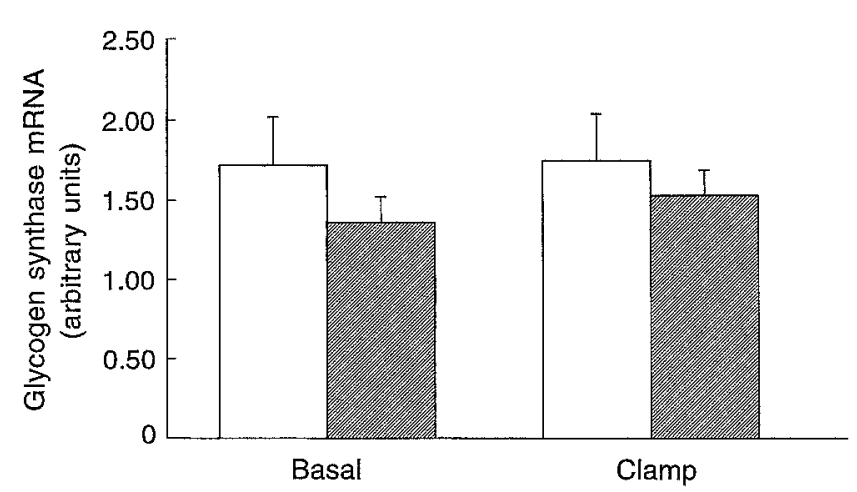

B
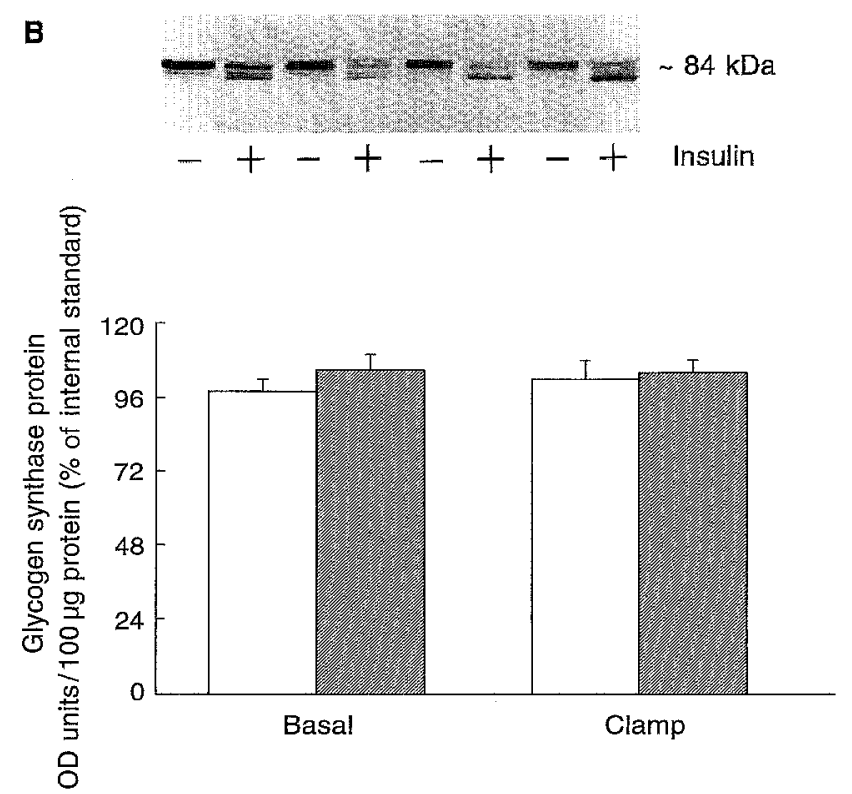

Fig.3 A Quantification of glycogen synthase (GS) mRNA levels in skeletal muscle (vastus lateralis) from NIDDM patients in the basal state and after $4 \mathrm{~h}$ of euglycaemia and hyperinsu-

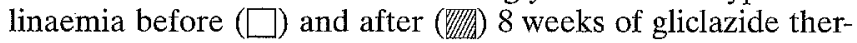
apy. No significant differences were found in the levels of GSspecific mRNA. B Autoradiograms of immunoblotting analysis of GS protein levels in skeletal muscle (vastus lateralis) from NIDDM patients in the basal state and after $4 \mathrm{~h}$ of euglycaemia and hyperinsulinaemia before and after 8 weeks of intervention. The blots in the upper panel are representative of ten NIDDM patients characterized in Table 1. Using a C-terminus antipeptide antibody against GS, a resolution of the dominant $84 \mathrm{kDa}$ band into more minor bands with apparent $\mathrm{M}_{\mathrm{r}}$ of $82-80 \mathrm{kDa}$ was recognized after $4 \mathrm{~h}$ of hyperinsulinaemia. This finding may reflect the dephosphorylating effect of insulin. Lower panel: results of densitometric scanning of autoradiograms. No differences were seen in GS immunoreactive mass before $(\square)$ or after ( Optical density

cients were comparable before and after intervention (NS), and they were equally reduced during insulin infusion before and after intervention (gliclazide group: $1.24 \pm 0.03$ vs $1.08 \pm 0.04, p=0.005$, before intervention and $1.24 \pm 0.03$ vs $1.05 \pm 0.05, p=0.007$, after intervention).
Table 3. Glycogen synthase (GS) activity in vastus lateralis muscle in the basal state and after $4 \mathrm{~h}$ of euglycaemic hyperinsulinaemia in NIDDM patients characterized in Table 1

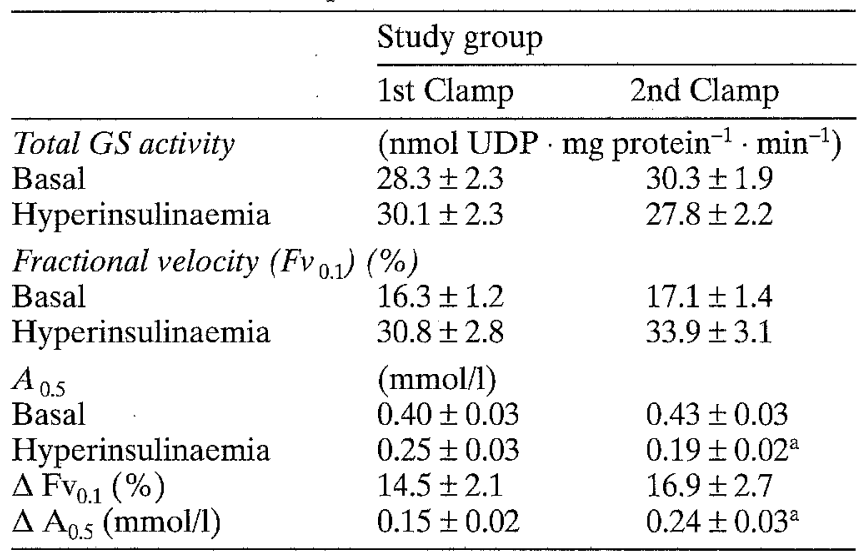

Means \pm SEM

${ }^{\mathrm{a}} p=0.01$ vs 1 st clamp

The second clamp was performed after 8 weeks of treatment with gliclazide

A significantly positive correlation was found between the increment in fractional activity of GS at the physiological G6P concentration of $0.1 \mathrm{mmol} / \mathrm{l}$ $\left(\triangle \mathrm{Fv}_{0.1}\right)$ and the increment in non-oxidative glucose metabolism during insulin infusion before and after treatment $(r=0.67, p=0.03$ and $r=0.76, p=0.01$, pre- and post-treatment respectively).

\section{Discussion}

We have previously demonstrated that NIDDM patients have a reduced mRNA expression of the muscle specific GS gene [4]. Thus, the main objective of the present study was to examine whether the impaired GS gene expression at the level of mRNA in skeletal muscle from insulin-resistant NIDDM patients [4] could be increased after chronic sulphonylurea treatment. However, despite significantly improved levels of fasting plasma glucose and $\mathrm{HbA}_{1 \mathrm{C}}$ as well as improved whole-body non-oxidative glucose metabolism and enhanced muscle GS activation no changes were found in the abundance of GS mRNA or GS immunoreactive mass in muscle from gliclazide-treated patients.

In another study of insulin-resistant NIDDM patients [17] we also demonstrated a disparity between reduced mRNA and normal protein expression of the muscle GS gene suggesting a difference in turnover rates related to either an increased translability of GS mRNA or an increased GS protein stability in patients with NIDDM. In studies of gastrocnemius muscle from rodents [35], induction of diabetes has been shown to reduce the overall protein synthesis rate due to a loss of tissue RNA and reduced translational efficiency, i.e., reduced protein synthesis per 
unit of RNA. Insulin treatment of these animals restored the efficiency of protein synthesis in muscle to the level of that observed in normal animals without any change in tissue RNA concentration. Therefore, insulin may change the rate of protein synthesis at the level of mRNA translation without a similar change in total RNA concentration [35]. Furthermore, insulin has been shown to have negative effects on the expression of specific genes [35, 36]. Since our data did not indicate a reversibility at the level of GS mRNA following intervention with sulphonylurea it may be hypothesized that the decreased level of GS mRNA in muscle from insulin-resistant NIDDM patients is not related to hyperglycaemia but may in part be caused by the prevailing slightly increased plasma insulin levels $[4,17]$. Furthermore, in NIDDM patients normal levels of GS protein despite lower GS mRNA levels might partly be caused by increased protein stability. Obviously, we cannot from our data rule out a primary genetic origin (e.g. structural defects in transcriptional factors) as a cause of decreased GS mRNA levels and lack of reversibility.

In NIDDM patients decreased non-oxidative glucose metabolism appears to be the predominant abnormality of insulin-stimulated glucose clearance of skeletal muscle [1] and studies of glucose-tolerant first-degree relatives of NIDDM patients have shown significantly reduced insulin-stimulated nonoxidative glucose metabolism at the whole body level [37] and a reduced activation of muscle GS by insulin [38] suggesting an inherited abnormality of glucose storage as glycogen. Most previous studies (see [1] for review) have demonstrated positive correlations between the whole body insulin-stimulated non-oxidative glucose metabolism and the activity of muscle GS. Both before and after gliclazide treatment we found a significantly positive correlation between the changes in non-oxidative metabolism and the changes in GS fractional activity at the physiological concentration of $\mathrm{G} 6 \mathrm{P}$ at $0.1 \mathrm{mmol} / \mathrm{l}$, thus substantiating previous findings [1].

Glycogen synthesis in skeletal muscle is allosterically stimulated by G6P and covalently stimulated by insulin. The stimulatory effect of G6P at physiological concentrations seems to be specific for GS and is most likely due to conformational changes of the enzyme which facilitates its dephosphorylation [39]. One possible explanation for the decreased allosteric activation of GS by G6P in NIDDM patients before intervention might be the occurrence of intervening metabolic factors which inhibit the physiological interaction between GS and G6P. The level of NEFA might be considered an intervening factor since studies in normal man have shown that intravenous infusion of triglycerides and heparin causes a severe decrease in muscle GS fractional activity. This effect is most likely due to an increase in the muscle content of long chain acyl-CoA which induces an inhibition of GS activity [40]. However, the insulinstimulated GS activation in the gliclazide-treated patients in the present study increased significantly although fasting and hyperinsulinaemic plasma levels of NEFA remained unchanged.

Finally, a few comments concerning the target tissues on which gliclazide may mediate its effects during chronic administration. Although basal serum insulin levels increased insignificantly following gliclazide treatment, a significant fall was demonstrated in the basal plasma glucose levels which suggests that the beta-cells secreted at least as much insulin despite lower plasma glucose levels. In addition, there was a trend to an increase in the mean incremental serum insulin AUC during the OGTT despite reduced glycaemic stimulus as reflected by the decreased mean incremental plasma glucose AUC. Similarly, the decrease in mean incremental plasma glucose AUC and the increase in mean incremental serum insulin after gliclazide treatment demonstrated a highly significant inverse relationship. Taken together, these results suggest that the chronic effect of gliclazide on blood glucose control in the examined obese NIDDM patients for a major part is mediated through the pancreatic beta-cells although we cannot exclude an additional effect on insulin clearance.

Whether chronic intake of sulphonylureas has direct extrapancreatic effects is a matter of dispute. Based on results obtained in insulin-dependent diabetic patients where sulphonylurea have failed to lower blood glucose $[41,42]$ it has been argued that any change in tissue insulin sensitivity during longterm sulphonylurea treatment may be due to improved metabolic control induced by the pancreatic effects of the drugs. Other investigators [43] have, however, reported that after 6 weeks of glyburide administration, total whole body glucose uptake improved in healthy control subjects despite unchanged fasting levels of serum insulin and plasma glucose. From the results of the present study we cannot determine whether the gliclazide associated effects on glucose metabolism and muscle GS activation were secondary to the long-term improvements in metabolic control. No significant correlations could, however, be shown between the change in $\mathrm{HbA}_{1 \mathrm{C}}$ and the change in muscle GS fractional activities $\left(\mathrm{FV}_{0.1}\right)$ or the half-maximal activation constant $\left(A_{0.5}\right)$ of GS in gliclazide-treated patients.

Acknowledgements. The technical assistance of Ms. A. Forman, L. Jensen, B. Motlau, L. Aabo, H. Fjordvang and L. Blak is gratefully acknowledged. This investigation was supported by grants from the Danish Diabetes Association, Poul and Erna Sehested Hansens Foundation, Jacob Madsens and Olga Madsens Foundation and the Institute de Recherches Internationales Servier. 


\section{References}

1. DeFronzo RA, Bonadonna R, Ferrannini E (1992) Pathogenesis of NIDDM. A balanced overview. Diabetes Care 15: $318-368$

2. Kida Y, Esposito-Del Puente A, Bogardus C, Mott DM (1990) Insulin resistance is associated with reduced fasting and insulin-stimulated glycogen synthase phosphatase activity in human skeletal muscle. J Clin Invest 85: 476-481

3. Thorburn AW, Gumbiner B, Bulacan F, Brechtel G, Henry RR (1991) Multiple defects in muscle glycogen synthase activity contribute to reduced glycogen synthesis in non-insulin-dependent diabetes mellitus. J Clin Invest 87: 489-495

4. Vestergaard H, Bjørbæk C, Andersen PH, Bak JF, Pedersen O (1991) Impaired expression of glycogen synthase mRNA in skeletal muscle of NIDDM patients. Diabetes 40: $1740-1745$

5. Johnson AB, Argyraki M, Thow JC et al. (1991) Impaired activation of skeletal muscle glycogen synthase in non-insulin-dependent diabetes mellitus is unrelated to degree of obesity. Metabolism 40: 252-260

6. Kelley DE, Mandarino LJ (1990) Hyperglycemia normalizes insulin-stimulated skeletal muscle glucose oxidation and storage in noninsulin-dependent diabetes mellitus. $J$ Clin Invest 86: 1999-2007

7. Damsbo P, Vaag A, Hother-Nielsen O, Beck-Nielsen $H$ (1991) Reduced glycogen synthase activity in skeletal muscle from obese patients with and without type 2 (noninsulin-dependent) diabetes mellitus. Diabetologia 34: 239-245

8. Johnson AB, Argyraki M, Thow JC, Broughton D, Jones IR, Taylor R (1990) Effects of intensive dietary treatment on insulin-stimulated skeletal muscle glycogen synthase activation and insulin secretion in newly presenting type $2 \mathrm{di}$ abetic patients. Diabet Med 7: 420-428

9. Shulman GI, Rothman DI, Jue T, Stein P, DeFronzo RA, Shulman RG (1990) Quantitation of muscle glycogen synthesis in normal subjects and subjects with non-insulin-dependent diabetes by ${ }^{13} \mathrm{C}$ nuclear magnetic resonance spectroscopy. N Engl J Med 322: 223-228

10. Johnson AB, Argyraki M, Thow JC, Jones IR, Broughton D, Taylor R (1990) The effect of sulphonylurea therapy on skeletal muscle glycogen synthase activity and insulin secretion in newly presenting type 2 (non-insulin-dependent) diabetic patients. Diabetic Medicine 8: 243-253

11. Bak JF, Møller N, Schmitz O, Saaek A, Pedersen O (1992) In vivo insulin action and muscle glycogen synthase activity in type 2 (non- insulin-dependent) diabetes mellitus: effects of diet treatment. Diabetologia 35: 777-784

12. Garvey WT, Olefsky JM, Griffin J, Hamman RF, Kolterman OG (1985) The effect of insulin treatment on insulin secretion and insulin action in type 2 diabetes mellitus. Diabetes 34: 222-234

13. Beck-Nielsen H, Hother-Nielsen O, Pedersen O (1988) Mechanism of action of sulphonylureas with special reference to the extrapancreatic effect: an overview. Diabet Med 5: 613-620

14. Vestergaard H, Weinreb JE, Rosen AS, et al (1995) Sulphonylurea therapy improves glucose disposal without changing skeletal muscle GLUT4 levels in non-insulin-dependent diabetes mellitus subjects: a longitudinal study. J Clin Endocrinol Metab 80: 270-275

15. National Diabetes Data Group (1979) Classification and diagnosis of diabetes mellitus and other categories of glucose intolerance. Diabetes 28: 1039-1057

16. DeFronzo RA, Tobin JD, Andres R (1979) Glucose clamp technique: a method for quantifying insulin secretion and resistance. Am J Physiol (Endocrinol Metab) 6(3):E214$\mathrm{E} 223$

17. Vestergaard H, Lund S, Larsen FS, Bjerrum OJ, Pedersen $\mathrm{O}$ (1993) Glycogen synthase and phosphofructokinase protein and $m$ RNA levels in skeletal muscle from insulin-resistant patients with non-insulin-dependent diabetes mellitus. J Clin Invest 91: 2342-2350

18. Steele $R$ (1959) Influence of glucose loading and of injected insulin on hepatic glucose output. Ann NY Acad Sci 82: $420-430$

19. Frayn KN (1983) Calculation of substrate oxidation rates in vivo from gaseous exchange. J Appl Physiol 55: 628-634

20. Wang AM, Doyle MV, Mark DF (1989) Quantitation of mRNA by polymerase chain reaction. Proc Natl Acad Sci USA 86: 9717-9721

21. Becker-André M, Hahlbrock K (1989) Absolute mRNA quantification using the polymerase chain reaction (PCR). A novel approach by a PCR aided transcript titration assay (PATTY). Nucleic Acids Res 17: 9437-9446

22. Mocharla H, Mocharla R, Hodes ME (1990) Coupled reverse transcription-polymerase chain reaction (RT-PCR) as a sensitive and rapid method for isozyme genotyping. Gene 93: 271-275

23. Siebert PD, Fukuda M (1985) Induction of cytoskeletal vimentin and actin gene expression by a tumor-promoting phorbol ester in human leukemic cell line K562. J Biol Chem 260: 3868-3874

24. Elder PK, French CL, Subramaniam M, Scmidt LJ, Getz MJ (1988) Evidence that the functional $\beta$-actin gene is single copy in most mice and is associated with $5^{\prime}$ sequences capable of conferring serum- and cycloheximide-dependent regulation. Mol Cell Biol 8: 480-485

25. Schmidt EE, Merrill GF (1991) Changes in dihydrofolate reductase (DHFR) mRNA levels can account fully for changes in DHFR synthesis rates during terminal differentation in a highly amplified myogenic cell line. Mol Cell Biol 11: 3726-3734

26. Efstratiadis A, Kafatos FC, Maniatis T (1977) The primary structure of rabbit $\beta$-globin mRNA as determined from cloned DNA. Cell 10: 571-585

27. Browner MF, Nakano K, Bang AG, Fletterick RJ (1989) Human muscle glycogen synthase cDNA sequence: a negatively charged protein with an asymmetric charge distribution. Proc Natl Acad Sci USA 86: 1443-1447

28. Bak JF, Pedersen O (1990) Exercise-enhanced activation of glycogen synthase in human skeletal muscle. Am J Physiol (Endocrinol Metab) 258:E957-E963

29. Andersen I, Hannibal S (1983) Analytical and economical optimization of a glucose method with immobilized enzymes. J Autom Chem 5: 188-192

30. Lanng S, Thorsteinsson B, Røder ME et al, (1993) Pancreas and gut hormone responses to oral glucose and intravenous glucagon in cystic fibrosis patients with normal, impaired, and diabetic glucose tolerance. Acta Endocrinol (Copenh) 128: 207-214

31. Heding LG (1975) Radioimmunological determination of human C-peptide in serum. Diabetologia 11: 541-548

32. Hother-Nielsen O, Schmitz O, Bak JF, Beck-Nielsen H (1987) Enhanced hepatic insulin sensitivity, but peripheral insulin resistance in patients with type 1 (insulin-dependent) diabetes. Diabetologia 30: 834-840

33. Itaya K, Michio U (1965) Colorimetric determination of free fatty acids in biological fluids. J Lipid Res 6: 16-20

34. Gray DS, Bray GA, Gemayel N, Kaplan K (1989) Effect of obesity on bioelectrical impedance. Am J Clin Nutr 50: $255-260$ 
35. Jefferson LS (1980) Role of insulin in the regulation of protein synthesis (Lilly Lecture 1979). Diabetes 29: 487-496

36. O'Brien RM, Granner DK (1991) Regulation of gene expression by insulin. Biochem J 278: 609-619

37. Eriksson J, Franssila-Kullunki A, Ekstrand A, et al (1989) Early metabolic defects in persons at increased risk for non-insulin- dependent diabetes mellitus. N Engl J Med 321: $337-343$

38. Schalin-Jäntti C, Härkönen M, Groop L (1992) Impaired activation of glycogen synthase in people at increased risk for developing NIDDM. Diabetes 41: 598-604

39. Villar-Palasi C (1991) Substrate specific activation by glucose 6-phosphate of the dephosphorylation of muscle glycogen synthase. Biochi Biophys Acta 1095: 261-267
40. Boden G, Jadali F, White J et al. (1991) Effects of fat on insulin-stimulated carbohydrate metabolism in normal men. J Clin Invest 88: 960-966

41. Grunberger G, Ryan J, Gorden P (1982) Sulfonyureas do not affect insulin binding or glycemic control in insulin-dependent diabetics. Diabetes 31: 890-896

42. Ratzmann KP, Schulz B, Heinke P, Besch W (1984) Tolbutamide does not alter insulin requirement in type 1 (insulin-dependent) diabetes. Diabetologia 27: 8-12

43. Simonson DC, Ferrannini E, Bevilacqua S et al. (1984) Mechanism of improvement in glucose metabolism after glyburide therapy. Diabetes 33: 838-845 